\title{
STUDIES ON THE PATTERN OF OCCURRENCE OF SOIL SEED BANK OF MONODORA MYRISTICA IN UMUAHIA, ABIA STATE, NIGERIA.
}

P. C. OGBONNA

(Received 6 May , 2008; Revision Accepted 21 January, 2009)

\begin{abstract}
The study on soil seed bank of three stands of Monodora myristica was carried out in Ohiya, Umuahia South of Abia State, Nigeria. Three soil depth of $0-5 \mathrm{~cm}, 5-10 \mathrm{~cm}$ and $10-20 \mathrm{~cm}$ (control) were dug at four cardinal points from the stands at a distance of $0 \mathrm{~m}, 3 \mathrm{~m}$ and $7 \mathrm{~m}$ (i.e. control) respectively. The total number of seeds deposited at the 0 $5 \mathrm{~cm}$ depth at $0 \mathrm{~m}(8.583), 3 \mathrm{~m}(14.250)$ and $7 \mathrm{~m}(3.000)$ were significantly higher than that deposited within the $5-10 \mathrm{~cm}$ (3.333, 5.917 and 0.833 ) and the $10-20 \mathrm{~cm}$ depth $(0.250,1.750$ and 0.000$)$ respectively. Over $70 \%$ of the seeds of Monodora myristica occurred within the $0-5 \mathrm{~cm}$ depth, $25 \%$ were deposited at the $5-10 \mathrm{~cm}$ depth while the control had about $5 \%$ seed occurrence. The highest number of seeds occurred at the distance of $3 \mathrm{~m}$ while the control had the lowest. The highest level of interaction between distance and soil depth occurred within the $0-5 \mathrm{~cm}$ and $3 \mathrm{~m}$. The pattern of seed occurrence in the soil may be attributed to the size and shape of the seeds of this tree specie.
\end{abstract}

KEY WORDS: Monodora myristica, seed bank, soil depth, distance.

\section{INTRODUCTION}

Soil seed bank is the store of dormant seeds within the soil of the terrestrial ecosystem and also the product of seed dispersal by plants. It contributes to vegetation recovery after disturbances such as tree felling or fire incidence in natural or semi-natural forests (Morgan and Neuenschwander, 1987; Kramer and Johnson, 1961). In forest plantations, buried viable seeds are critical for vegetation recovery after clearcutting as well as for re-growth of forest floor vegetation (Hill and Stevens, 1981). It also aids in rapid revegetation of burnt or ploughed sites.

Plants are capable of maintaining their population mainly through viable seed buried in the soil. The size and quantity of seed bank produced and the number of seeds that germinated depend on viable seed production and the number that persisted in the soil. Seed in soil can be dormant for a year or decades depending on the species (Schopmeger, 1974). Akobundu and Ekeleme (2002) found that fast growing multi-purpose species reduce weed build up. Abiotic factors can also have a noticeable effect on the make-up of seed banks (Hyatt and Casper, 2000). Some of these factors affecting seed germination are temperature change and rainfall intensity (Hyatt, 1999). Also, Falinska (1999) found that post-agricultural land tract showed a decrease in richness in seed bank over five years.

The rainforest of Nigeria used to abound in Monodora myristica (nutmeg) whose seed contribute to local diet in developing countries. The seeds are used as major food supplement such as condiments, edible oil, flavours and in the treatment of ailment. Also, it is an important source of vitamins, minerals, fats and oil. The consumption of Monodora myristica is fast declining in many regions particularly in the south eastern Nigeria. Presently, the status of Monodora myristica is endangered due to poor germinability of seeds and deforestation. Therefore, this study is aimed at understanding the pattern of seed occurrence of this important plant specie in the soil seed bank.

\section{MATERIALS AND METHODS}

\section{Study Area}

The assessment of soil seed bank of Monodora myristica was carried out in Ohiya, Umuahia South Local Government Area of Abia State, Nigeria. The 67 year Monodora myristica stands have a mean height of $14.6 \mathrm{~m}$ while the mean diameter-at-breast height was $86.3 \mathrm{~cm}$. Ohiya is within the lowland rainforest zone of Nigeria (Keay, 1959) which lies on latitude $05^{\circ} 17^{\prime} \mathrm{N}$ and longitude $07^{\circ} 03^{\prime} \mathrm{E}$. The area has a mean annual rainfall of $2133 \mathrm{~mm}$ distributed over eight months of rainy season period (March to October) with bimodal peak in July and September. The soil is ultisol. The minimum and maximum temperature is $21^{\circ} \mathrm{C}$ and $30^{\circ} \mathrm{C}$ respectively, with relative humidity of $60-70 \%$.

\section{Sample Collection}

Soil samples were collected from three stands of Monodora myristica at three different soil depths of 0$5 \mathrm{~cm}, 5-10 \mathrm{~cm}$, and $10-20 \mathrm{~cm}$. The soil depths were established at four cardinal points from each stand at three distances $0 \mathrm{~m}, 3 \mathrm{~m}$, and $7 \mathrm{~m}$. Soil samples were collected with soil auger and measuring tape, and each soil sample was stored in well labelled soil bags. Each soil bag was emptied into aluminium trays and the seeds of Monodora myristica present in the sample were carefully identified and counted.

The data collected were subjected to analysis of variance, and mean separation by Duncan New Multiple Range Test was carried out according to Steel and Torrie (1980). The experimental design is a 2 factorial experiment in randomized complete block design (RCBD) where factor $A$ is depth and factor $B$ distance.

P. C. Ogbonna, Dept of Forestry and Environmental Mgt, Michael Okpara Univ. of Agric., Umudike, PMB 7267 Umuahia, Abia State, Nigeria. 


\section{RESULTS AND DISCUSSION}

\section{PATTERN OF OCCURRENCE OF SOIL SEEDBANK OF Monodora myristica IN THE SOIL \\ The seed bank of Monodora myristica at} different soil depth is not similar. The total number of seeds located within the $0-5 \mathrm{~cm}$ soil depth at $0 \mathrm{~m}(8.583)$, $3 \mathrm{~m}(14.250)$ and $7 \mathrm{~m}$ (3.000) were significantly higher than that found within the $5-10(3.333,5.917$ and 0.833$)$ depth and the $10-20 \mathrm{~cm}$ depth $(0.250,1.750$ and 0.000$)$ respectively (Table 1 ). Within the $0-5 \mathrm{~cm}$ depth, the highest number of seeds of Monodora myristica were deposited at the distance of $3 \mathrm{~m}$ (14.520), followed by the $0 \mathrm{~m}(8.583)$ while the control $(7 \mathrm{~m})$ has the lowest value (3.000). However, the number of seeds deposited within the $5-10 \mathrm{~cm}$ depth $(3.333,5.917$ and 0.833$)$ across the various distances was significantly higher than the control $(10-20 \mathrm{~cm})$ depth.

Table 1: Seed bank of Monodora myristica at different soil depth

\begin{tabular}{llllll}
\hline Distance from tree (m) & $\mathbf{0 - 5}$ & $\mathbf{5 - 1 0}$ & $\mathbf{1 0 - 2 0}$ & \multirow{2}{*}{ Remark } & SEM \\
\hline 0 & $8.583^{\mathrm{a}}$ & $3.333^{\mathrm{b}}$ & $0.250^{\mathrm{c}}$ & $*$ & 1.155 \\
3 & $14.250^{\mathrm{a}}$ & $5.917^{\mathrm{b}}$ & $1.750^{\mathrm{c}}$ & $*$ & 1.961 \\
7 & $3.000^{\mathrm{a}}$ & $0.833^{\mathrm{b}}$ & $0.000^{\mathrm{c}}$ & $*$ & 0.757
\end{tabular}

$a, b, c=$ means with different superscript are significantly different at $\mathrm{P}<0.05$

* $\quad=$ significant difference

Table 2: Effect of distance on mean number of seeds of Monodora myristica in the soil

\begin{tabular}{lllll}
\hline Om & $3 \mathrm{~m}$ & $\mathbf{7 m}$ & Remark & SEM \\
\hline 4.056 & 7.306 & 1.278 & $*$ & 1.990
\end{tabular}

$\mathrm{a}, \mathrm{b}, \mathrm{c}=$ means with different superscript are significantly different at $\mathrm{P}<0.05$

$=$ significant difference

The result also shows that over $70 \%$ of the seeds of Monodora myristica occurred within the $0-5 \mathrm{~cm}$ depth and about $25 \%$ were deposited within the $5-10 \mathrm{~cm}$ depth while the control $(10-20 \mathrm{~cm}$ depth) has about $5 \%$ seed occurrence. The pattern of occurrence or deposition of the seeds within the various soil depths may be attributed to the size and shape of the seeds of this tree specie. The seeds are big and may not easily percolate through the soil to greater depths. Soil structure and texture can also affect the deposition pattern of seeds within the seed bank of tree species. From Table 1, the total number of seeds deposited at the various soil depth decreases progressively with increase in soil depth.

Total mean number of seeds of Monodora myristica deposited at various distances from the tree stands is shown in table 2. However, the mean numbers of seeds deposited at different distances from the stem base are not similar. The highest number of seeds was deposited at $3 \mathrm{~m}(7.306)$, followed by the $0 \mathrm{~m}(4.056)$ while the $7 \mathrm{~m}$ (i.e. control) had the lowest (1.278). In this study, the deposition pattern of seeds with respect to distances may be attributed to the length of the branches and the tallness of the trees. When trees are very tall (above 20 metres), fruits which did not hit any lower branch when falling will reach the soil surface with high velocity thus, dispersing its seeds to several meters away. The deposition pattern of seeds of plant species at various distances from stem base may also be affected by the canopy cover of the trees and animals, including man..

Table 3: Interaction between distances and soil depth on soil seed bank of Monodora myristica

\begin{tabular}{lllll}
\hline Soil depth $(\mathbf{c m})$ & $\mathbf{0}$ & $\mathbf{3}$ & $\mathbf{7}$ & Mean \\
\hline $0-5$ & $8.583^{\mathrm{b}}$ & $14.250^{\mathrm{a}}$ & $3.000^{\mathrm{c}}$ & $8.611^{\mathrm{a}}$ \\
5.10 & $2.917^{\mathrm{d}}$ & $5.917^{\mathrm{c}}$ & $0.833^{\mathrm{e}, \mathrm{f}}$ & $3.222^{\mathrm{b}}$ \\
$10-20$ & $0.250^{\mathrm{e}, \mathrm{f}}$ & $1.750^{\mathrm{d}, \mathrm{e}}$ & $0.000^{\mathrm{f}}$ & $0.667^{\mathrm{c}}$ \\
Mean & $3.917^{\mathrm{b}}$ & $7.306^{\mathrm{a}}$ & $1.278^{\mathrm{c}}$ & \\
\end{tabular}

$\begin{array}{ll}\text { SEM DT } & =0.317^{*} \\ \text { SEM SD } & =0.317^{*} \\ \text { SEM DT } x \text { SD }=0.548^{*}\end{array}$

$a, b, c, d, e, f=$ Means with different superscripts are significantly different from each other at $(P<0.05)$. Means with the same superscripts are not significantly different from each other at $(P<0.05)$

SEM = Standard error of mean

$=$ Significant difference

DT, SD, DT x SD represents distance from tree stand, soil depth and interaction between distances form stand and soil depth respectively.

The interaction effect between the distances and the various soil depths from tree stand (stem base) were significantly different. The highest level of interaction between soil depth and different distances occurred within the $0-5 \mathrm{~cm}$ soil depth $(14.250)$ at a distance of $3 \mathrm{~m}$ from the stem base (Table 3). A higher level of significant difference (8.583) also occurred at the same soil depth $(0-5 \mathrm{~cm})$ but at a distance of $0 \mathrm{~m}$, which is followed by the $5-10 \mathrm{~cm}$ depth (5.917) at a distance of $3 \mathrm{~m}$ from the stem base. However, the least level of 
significant difference occurred within the $10-20 \mathrm{~cm}$ depth $(0.250,1.750$ and 0.000$)$ at the distances of $0 \mathrm{~m}, 3 \mathrm{~m}$ and $7 \mathrm{~m}$ respectively.

\section{POTENTIAL VIABILITY OF THE SEEDS FROM SEED BANK OF Monodora myristica}

The viability potential of the seeds planted in poly-pots was zero. That is, none of the seeds germinated. Certain factors such as allelopathic substances, fungal and bacterial attack, ageing as well as predation may reduce the viability potentials of seeds deposited within the soil seed bank of plant species. Seeds are said to be viable only when they are able to germinate within a period of time under favourable condition. The failure of the seeds of Monodora myristica deposited within the various soil depths to germinate after planting may be as a result of lack of micro sites and age of the seeds. Most perennial plants with big seeds do not remain dormant for a long period of time in the soil systems.

\section{CONCLUSION}

The research has documented basic information on the pattern of occurrence of soil seed bank of Monodora myristica. The study has shown that the seeds of Monodora myristica have limitation in terms of range of distribution within the various soil depth and distances from the soil surface and stem base respectively. Over $70 \%$ of the seeds of Monodora myristica occurred within the $0-5 \mathrm{~cm}$ depth at a distance of $3 \mathrm{~m}$. This pattern of occurrence within the soil system does not constitute any difficulty to be picked by man and other predatory organisms, which may affect its sustainability as important plant specie.

The following recommendations are made, based on the results of the studies:

i. The gathering of the seeds of Monodora myristica by the rural people should be regulated to avoid total consumption and/or utilization of the seeds as condiment and sauce by these group of people,

ii. Enrichment planting of Monodora myristica should be promoted in the remaining rainforest estate,

iii. Seedlings of Monodora myristica should be planted in home gardens so as to enhance its sustainability,

iv. Government agencies such as Agricultural Development Programme
(ADP) should assist in the raising of seedlings of Monodora myristica, which will be given to farmers as incentives (free of charge).

\section{REFERENCES}

Akobundu, O. and Ekeleme, F., 2002. Weed seed bank characteristics of arable fields under different fallow management systems in the human tropical zone of south eastern Nigeria. Agroforestry Systems 54: 161-170.

Falinska, K., 1999. Seed bank dynamics in abandoned meadows during a 20 -year period in the Bialowieza National Park. Journal of Ecology 88: 594-607.

Hill, M. O. and Stevens, P. A., 1999. The diversity of viable seed in soils of forest plantation in upland. Britain J. Ecol. (1981) 69: 693-709.

Hyatt, A.and Casper, B. B., 2000. Seed bank formation during early secondary succession in a temperate deciduous forest. Journal of Ecology 88: 516-527.

Hyatt, L., 1999. Differences between seed bank composition and field recruitment in a temperate zone deciduous forest. The American Midland Naturalist, 142: 31-38.

Keay, R. W. J., 1959. An outlines of Nigeria vegetation. $3^{\text {rd }}$ edn. Government Printer, Lagos, 43pp.

Kramer, N. B. and Johnson, F. D., 1961. Mature forest seed banks of three habitat types in central Idaho. Can. J. Bot. 65: 1961-1966.

Morgan, P. and Neuenschwander, L. F., 1987. Seed bank contributions to regeneration of shrub species after clear-cutting and burning. Can. J. Bot. 66: 169-172.

Schopmerger, C. S., 1974. Seed of woody plants in United States. United States Department of Agriculture, Washington, D.C., Handbook No. 450.

Steel, R. G. D. and Torrie, J. H., 1980. Principles and Procedures of Statistics: A Biometric Approach. McGraw-Hill Publication, New York, 633pp. 